\title{
Miscarriage of Justice in the Commonwealth Jermaine Pickett
}

$\mathrm{T}$

There is a practice in the Commonwealth of Virginia that is being ignored or has gone unrecognized. The people responsible for upholding and protecting the Constitution have introduced a new system of law to obtain convictions. As I will elaborate below, this system of so-called justice is based on deceptive tactics including coercion, bribery, manipulation and fraud. Tactics are utilized to advance political careers and support lavish lifestyles. The Commonwealth will go to any extreme to gain a conviction.

Citizens of Virginia should be aware that the state judicial system has even coerced people into pleading guilty to crimes they did not commit. What happened to me is one such example. In 2005, I was arrested and indicted for first-degree murder.

While awaiting trial, I declined a plea the prosecutor offered me. In 2006, two days before my trial date, the prosecutor nolle prosequi (non-processed) the first-degree murder charge and re-indicted me on a more serious charge - murder for hire, a capital offense punishable by death. My attorneys conspired with the prosecutor to obtain a more lucrative conviction for the state. The summary of the facts presented by the prosecutor during my plea colloquy (plea hearing) did not support the statute of capital murder for hire (Va. Code $\S 18.2-31$ subsection 2). Although my attorneys knew this, they still advised me to plead guilty to avoid the death penalty. The judge presiding over my case knew that the facts presented did not constitute the charge of murder for hire. The prosecutor made it known on record "that the victim was not the intended target". According to Virginia law, it is unlawful to be convicted of capital murder for an unintended victim. In the September 2007 case of Jordon v. Commonwealth, the court held: "A charge of completed capital murder, like attempted capital murder requires proof of a specific intent to kill the victim" (Jordan v. Commonwealth. 50 Va. App. 322 [September 4, 2007]).

Before accepting a plea of guilty, the judge must determine that there is a factual basis (McCarthy. U.S. 394 U.S. 459 (1969); Jones v. Commonwealth. 29 Va. App. 503 (1999)). It is the judge's duty to determine that the conduct to which the defendant admits constitutes the offense charged in the indictment, information or an offense included therein to which the defendant has pleaded guilty. The defendant is in the position of pleading voluntarily without realizing that his conduct does not actually fall within the nature of the charge. It follows that I was fraudulently coerced 
into pleading guilty to a crime I did not commit. This makes my conviction and sentence null and void.

Stories like my own are examples of the gross miscarriage of justice that is created when officials manipulate the court system for their own personal gain. Commonwealth attorneys often coerce defendants or pay other felons (especially prisoners awaiting trial) to give false testimony and, in effect, solicit perjury. Usually, this payment is in the form of a guarantee of a reduced sentence or non-prosecution for the crime they committed. These facts illustrate the lengths the Commonwealth will go to gain more lucrative convictions. The public needs to be aware of this gross injustice.

\section{ABOUT THE AUTHOR}

Jermaine Pickett was born in 1976 in Richmond, Virginia, to Depriest and Brend Pickett. He has four siblings. A father of three children, Jermaine has two grandchildren. Growing up in Gpilin Housing Project on the North side of Richmond, he was fascinated by animals and had a dream of being a veterinarian, nut that dream was deferred when he grew into a reckless teenager caught up in the "street culture". This way of life carried over into his adulthood. He is serving a natural life plus eighteen-year sentence. If you would like to know more about Jermaine's story, he can be reached by mail at:

Jermaine Pickett

\#1191301

Keen Mountain Correctional Centre

P.O. Box 860

Oakwood, Virginia, 24631

USA 